University of South Florida

DIGITAL COMMONS

Digital Commons @ University of

@ UNIVERSITY OF SOUTH FLORIDA

South Florida

USF St. Petersburg campus Faculty

Publications

USF Faculty Publications

2008

\title{
Using science notebooks to improve writing skills and conceptual understanding.
}

Malcolm B. Butler

Catherine Nesbit

Follow this and additional works at: https://digitalcommons.usf.edu/fac_publications

\section{Recommended Citation}

This is an electronic version of an article published as Butler, M.B. \& Nesbit, C. (2008). Using science notebooks to improve writing skills and conceptual understanding. Science Activities, 44(4), 137-146. Science Activities is available online at http://www.tandfonline.com/openurl?genre=article\&issn= 0036-8121 \&date $=2008 \&$ volume $=44 \&$ issue $=4 \&$ spage $=137$

This Article is brought to you for free and open access by the USF Faculty Publications at Digital Commons @ University of South Florida. It has been accepted for inclusion in USF St. Petersburg campus Faculty Publications by an authorized administrator of Digital Commons @ University of South Florida. For more information, please contact digitalcommons@usf.edu. 


\title{
Using Science Notebooks to Improve Writing Skills and Conceptual Understanding
}

\begin{abstract}
The purpose of this article is to provide teachers with strategies for improving students' writing and deepening their conceptual understanding through the use of Science Notebooks. The strategies include using various resources and providing a variety of feedback opportunities for students. A sample science investigation and an accompanying Science Notebook entry illustrating the strategies are presented.
\end{abstract}

Key Words

conceptual knowledge, lines of learning, science notebooks, teacher feedback, writing skills

\section{Background}

Science Notebooks are where students describe in writing the experiments they are performing and their interpretation of the results. Writing in notebooks is structured around the use of the science process skills. Communication is one of those essential skills. This skill is critical because without it scientists would not be able to share their scientific findings with the public. Thus, teaching students how to write and discuss their experimental findings in a clear, understandable manner is an important goal for every science teacher.

From our experiences working with classroom teachers, we have found that a typical Science Notebook entry has six parts: Date and Time, Question, Prediction, Procedure that includes Collection of Data, Conclusions and the Line of Learning. Although there can be six parts in an investigation, it is important to note that every Science Notebook entry will not necessarily have each of these components. (See Table 1 for descriptions of the parts of a Science Notebooks Entry.)

When learners write in Science Notebooks, they discover what they think and come to a better understanding of what they know and what gaps remain in their knowledge. This metacognitive awareness produced by writing can serve as a catalyst for further learning. Shepardson and Britsch (1997, 
p. 15) state "Written reflection is essential to promote children's explorations of their own thinking and learning process." Research shows increased student achievement when student writing is accompanied by an active science program (Klentschy, Garrison, \& Amaral 1999). Fourth graders in El Centro School District more than doubled their statewide standardized test scores in science and reading, and almost doubled their scores in mathematics. An even more astonishing outcome of the program involves sixth graders' writing scores. After experiencing the program for four years, these sixth graders' writing scores almost quadrupled! Another important point to highlight is the large percentage of English Language Learners that are enrolled in the El Centro schools.

There are several purposes for writing in notebooks. One may be to generate a record of science experiences. In this case, notebooks might be expected to contain descriptions of what was done, how it was done, and what resulted. Still another purpose may be to develop conceptual understanding (Shepardson \& Britsch 1997). When notebooks focus on making sense of investigations, students would be modifying, reflecting upon, organizing and connecting their knowledge thus deepening their conceptual understanding. Writing for the purpose of making sense of the investigation involves students in constructing knowledge. When this happens, students move from the predominant "knowledge-telling" model, where knowledge from memory is transcribed onto paper unaltered, to a "knowledgetransforming" model where knowledge is constructed (Scardamalia \& Bereiter 1968, p. 16).

The teacher's directions when using Science Notebooks with their students influence the quantity, quality, and organization of the entries. The amount of learning that takes place depends upon how the teacher conveys the purpose for writing to the students. In other words, will the teacher merely emphasize what was done in the experiment and neglect writing as a way of thinking about and learning science concepts? "The national standards challenge educators to move beyond 'science as a process' in which students learn skills (observing, inferring, and hypothesizing) and to combine these skills with scientific knowledge, scientific reasoning, and critical thinking to construct a richer understanding of science" (Bybee 1997, p. 11). 
This article will illustrate how teachers can enhance student thinking as they write in Science Notebooks. We will do this by presenting an investigation that illustrates a variety of strategies teachers can use to deepen conceptual knowledge and improve writing skills. A fairly simple science investigation was chosen to focus on the strategies used rather than the experiment itself.

\section{A Sample Science Investigation and An Accompanying Science Notebook Entry}

At the beginning of each science investigation, students in Mrs. Bee's sixth grade class know to write the date and the time in their notebooks. The students know this is important because it's been explained to them that scientists must keep detailed records so they can effectively document and report their findings. Based upon a previous experiment in which the students were investigating the properties of water, Mrs. Bee poses the question, How many water drops fit on a penny? The students write the question in their notebooks. The students then make a prediction. As the students talk to their partner about their prediction, Mrs. Bee reminds them to make an educated guess and include reasons for the prediction they make. (See Figure 1 for Carla's prediction entry). Carla looked at the size of the penny and the size of the drop, which helped her make the prediction she did. Next is the procedure. The class discusses the importance of controlling variables in the experiment so as to conduct a fair test. Some of the possible variables students talk and write about include: the height the water is dropped, the type of dropper used, and the side of the penny used. Students write the procedure they use. Mrs. Bee expects detail and exactness in this part. To reinforce this, she asks students to share their written procedures with a partner. Each partner reads the procedural steps and follows the directions precisely. This process makes students aware of the accuracy and clarity of their written communication and if need be they make corrections. Students collect and record their data in a way that makes the most sense to them: some do labeled drawings, some do a chart and /or graph, and some write a description of the data. As they proceed through the experiment, several questions arise and many students choose to pursue them. For example, Carla wanted to see if the heads or the tails held more drops (See Figure 2 for her entry.) Now 
conclusions are made. Most students are surprised to see the number of drops the penny actually holds and record this in their conclusion.

\section{Lines of Learning}

At this point, students usually want to stop because they got their answer and so they are ready to move on to another investigation. However, Mrs. Bee knows this next part of the experiment, the Line of Learning (See Table 1 for a description of this component of the Science Notebook), is crucially important to help the students develop understanding of the science content related to the experiment. She prompts the students to draw a line and label this section LOL (Line of Learning). Mrs. Bee then talks to the whole class about their conclusions. During this discussion students use words such as the water acted like glue because it stuck together or the water acted like it was magnetized because it hung together. Mrs. Bee accepts these descriptions because they are good operational definitions and then she introduces the science vocabulary, "cohesion" and "surface tension". After the discussion students are given time to write what they learned during class discussion. Many consult each other as they write. (See Figure 3 for Carla's first LOL entry.) At this point Mrs. Bee sends the students to search in textbooks, trade books and the internet to find more exact definitions and examples of surface tension. Once these definitions are found the students add a new LOL entry in the science notebook (See Figure 4 for Carla's second LOL entry). While searching the internet Carla finds information on the water strider and how it can walk on water. Her third LOL entry includes a picture of the water strider and she writes how the water strider's ability to walk on water relates to surface tension (See Figure 5 for Carla's third LOL entry.). Other students find investigations like water maze races and model water molecules that demonstrate why water molecules adhere to each other.

Each of the resources described previously (teacher, textbooks, trade books, and internet) help the students extend their learning of surface tension as they revisit the concept several times in the Line of Learning sections of their notebooks. The process of writing is important "not only for learning about 
something or acquiring knowledge, but also for generating a personal response to something, for clarifying ideas, and for constructing knowledge.” (Rivard, 1994, p. 970).

\section{The Role of Feedback}

Another effective strategy for extending students' conceptual understanding and improving writing skills is to provide multiple opportunities for receiving feedback. John Hattie (1992) concludes that the most powerful single modification that enhances achievement is feedback. This article will describe several types of feedback opportunities used with Science Notebooks: students completing a self evaluation rubric, students working with peers, written teacher feedback, science teacher conferences with individual students, students working with the language arts teacher, and students publishing and presenting their work at a science conference.

Students assess their own notebooks using a rubric developed by the teacher and students. The rubric can focus on the clarity of writing as well as the accuracy and completeness of the science content. Having used the rubric, students often discover they didn't complete the criteria or did it incorrectly. At this point, they have the opportunity to go back and make revisions to the entry.

Having a peer evaluate notebook entries can be very helpful in assisting students in writing clearly. Often students think they have communicated clearly, but when someone else reads the passage it is not understood. Based upon effective feedback, the students can make a new entry stating their new ideas, thoughts, or make revisions to an existing entry.

Teachers can provide written feedback in notebooks, such as asking questions that stimulate the students to move forward in their thinking. The importance of writing as an essential component of science inquiry can be supported or tempered by the teacher's attention to various aspects of writing. For example, monitoring of activity completion versus monitoring of understanding of what was done signals for the students the relative value of doing over learning. Likewise, feedback consistently focused on structural or organizational aspects of record keeping such as spelling or labelng diverts attention from the questioning, reasoning, and hypothesizing central to inquiry. Teachers discover that providing students 
with feedback in terms of specific levels of knowledge and skill is better than simply providing students with a percentage score (Marzano 2001). We suggest that teachers give their feedback on "sticky" notes or some other form, so that they are not doing a significant amount of writing in students' notebooks. Thus, students can maintain a sense of ownership of their writing.

Teachers can hold individual conferences with students where they explore students' thinking. Students' true understanding can be revealed when a teacher holds individual conferences with students. When a teacher structures various opportunities to provide feedback that pertains to the content of what was written, students' knowledge will improve (Matsumura, Patthey-Chavez, Valdes, \& Garnier 2002). Teachers also can give valuable feedback about the clarity of the students' writing. In other words, do students write what they think they did? Although it is unrealistic to think that teachers can hold conferences after each lesson with each student, when a teacher perceives that a misconception persists, then it is vital to confer. In addition, students often are able to verbalize and explain more to the teacher than what they are able to write on paper.

An authentic culminating experience is a science conference where students present their published work. Students choose one of their best works from their Science Notebook entries for publication. It is important to note that at this point the Science Notebook entries have been reviewed only for written clarity and for conceptual understanding. For publication purposes, their work now needs to be reviewed for mechanical aspects, such as complete sentences, subject and verb agreement and spelling. Either the science teacher or the language arts teacher can help by giving students feedback on these aspects.

Receiving effective feedback, as these examples show, can provide students with the opportunity to go back to their notebooks and add a new entry with reformulated information or to make revisions to existing entries. It takes TIME to transform knowledge. When students write in their notebooks, teachers must provide MULTIPLE opportunities for students to GRAPPLE with their conceptual understanding of the experiment and multiple opportunities to RECORD these thoughts in their Science Notebooks as their ideas develop. 
When teachers provide students with opportunities to write about their science investigations, everyone benefits- teachers become better facilitators and students become better scientists and writers. This is the best scenario for improving science teaching and learning. 


\section{References and Resources}

Bybee, R.W. 1997. Achieving scientific literacy. Portsmouth, NH: Heinemann.

Hattie, J. 1992. Measuring the effects of schooling. Australian Journal of Education, 36(1): 5-13.

Klentschy, M., Garrison, L., \& Amaral, O.M. 1999. Valle imperial project in science four-year comparison of student achievement data, 1995-1999. El Centro, CA: El Centro Unified School District.

Marzano, Robert, 2001. A new era of school reform: Going where the research takes us. Aurora, CO: Mid-continent Research for Education and Learning.

Matsumura, L.C., Patthey-Chavez, G.G., Valdes, R., \& Garnier, H. 2002. Teacher feedback, writing assignment quality, and third-grade students' revision in lower and higher-achieving urban schools. The Elementary School Journal, 103(1): 3-25.

North Carolina Infrastructure for Science Education, http://www.nc-ise.org/new/index.htm (accessed May 10, 2006).

Rivard, L.P. (1994). A review of writing to learn science: Implications for practice and research. Journal of Research in Science Teaching, 31, 969-983.

Scardamalia, M., \& Bereiter, C. 1986. Helping students become better writers. School Administrator, 42(4): 16-26.

Shepardson, D.P., \& Britsch, S.J. 1997. Children's science journals: Tools for teaching, learning, and assessing. Science and Children, 34(5): 13-17, 46-47. 
Table 1. Six Parts of a Science Notebook Entry.

\begin{tabular}{|l|l|}
\hline \multicolumn{1}{|c|}{ Part } & \multicolumn{1}{c|}{ Description } \\
\hline Date and Time & $\begin{array}{l}\text { The key problem to be investigated. Questions may be posed by teacher or } \\
\text { generated by students. }\end{array}$ \\
\hline Question & Students make an educated guess and give an explanation/reason. \\
\hline Prediction & $\begin{array}{l}\text { All materials, steps, and collected data are recorded here. Data may be shown } \\
\text { in graphs, charts, or pictures. Another person should be able to read what was } \\
\text { done and be able to repeat it. }\end{array}$ \\
\hline Procedure & $\begin{array}{l}\text { Students tell what happened in the experiment. Often students use operational } \\
\text { definitions to describe the results. }\end{array}$ \\
\hline Conclusion & $\begin{array}{l}\text { Students develop deeper understanding about the target concept. They apply } \\
\text { the concept to new situations and learn new science vocabulary. }\end{array}$ \\
\hline Line of Learning & \\
\hline
\end{tabular}

Adapted from the North Carolina Infrastructure for Science Education Materials (2006): www.nc-ise.org. 
10

Figure 1. Carla's Question and Prediction.

$$
\begin{aligned}
& 9.8-05 \\
& 11: 00 \mathrm{am}
\end{aligned}
$$

Q3 How many water drops does a penny hold?

PI think it will take
4-6 drops to cover a penny because the drops are a big size and the penny is small. Also. there are not edges on the penny.

OK

actual water drop size

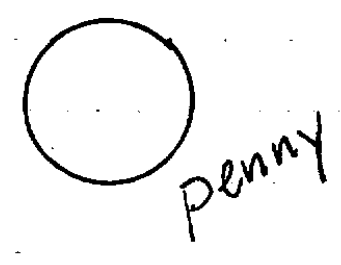

Heads may be more raised so it will hold less drops. 
11

Figure 2. Carla's Data Collection and Conclusion.

Recording of $\tilde{\Omega}_{\text {penny }}^{\text {water }}$

Recording of Data Heads

Trials Drops.

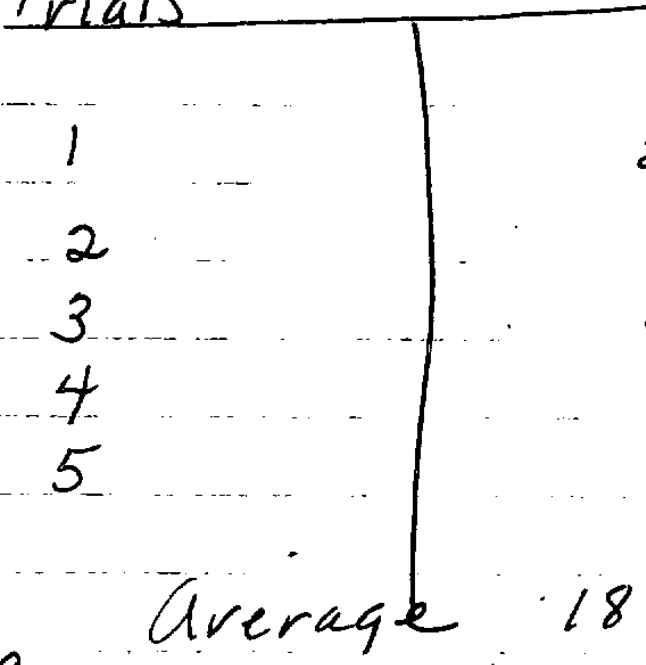

21

18

20

19

13

Compare Heads and Tails

Tails

$$
\begin{array}{c|c}
\text { Trials } & \text { Drops } \\
\hline 1 & 20 \\
2 & 21 \\
3 & 20 \\
4 & 16 \\
5 & 25
\end{array}
$$

average 20 expected. Heads hold less drops. 
12

Figure 3. Carla's First Line of Learning.

LDL

9.9 .05

Cohesion

water sticks together and makes the dome shape.

$$
\begin{aligned}
& \text { Skin }=\text { cohesion } \\
& \text { stays together (big) until } \\
& \text { it breaks. }
\end{aligned}
$$

surface tension

surface - wherever the

…water meets the air.

tension - holds tight 
13

Figure 4. Carla's Second Line of Learning.

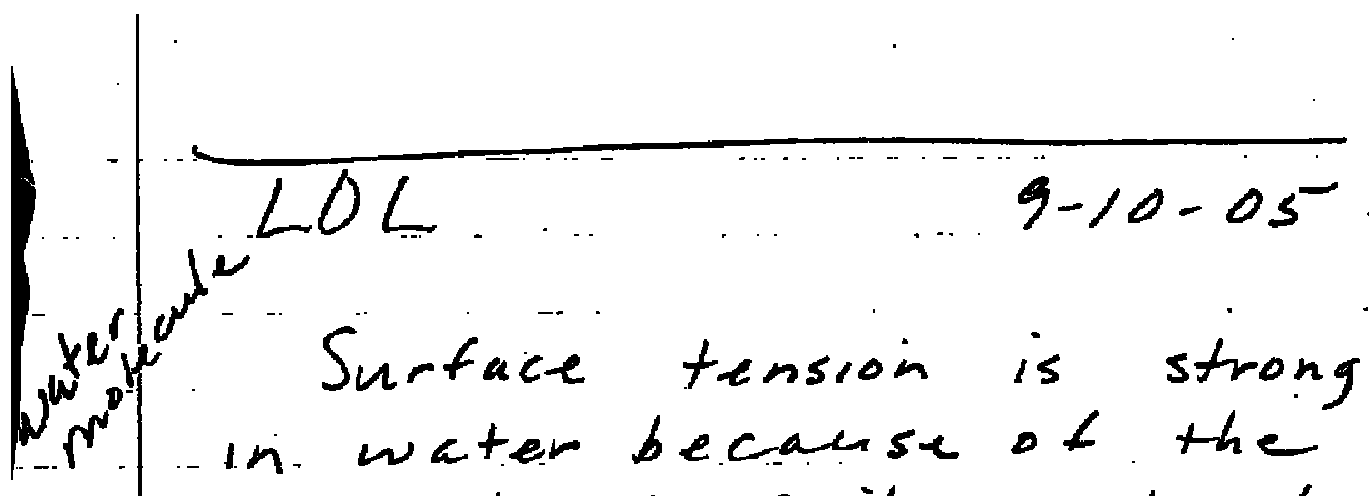

of tight bond of its. molecules. In this experiment, the water

H. bulged ip eve! the penny making a dome. The tension. of the water molecules.

and its bonds ... kept it from bursting. Another name fir the water molecules sticking together.. is cohesion. We also have cohesion of our - skin... because it holds together what is inside ( blood, veins, muscle). 
14

Figure 5. Carla's Third Line of Learning.

LL

$9-11-05$

Walking on Water

Water strides are light and the water sticks together and can bend

- and bulge.: The legs cause dimples in the water... The surface tension of the water does not break when water strides walk on the water.

$$
\sum_{0^{r} x^{a^{q^{2}}}} k^{k^{i^{4}}}
$$

